Utah State University

DigitalCommons@USU

2013

\title{
Merging Two Academic Libraries: Finding Unity from Diversity while Maintaining Institutional Identities
}

\author{
Betty Rozum \\ Utah State University \\ Lori Brassaw \\ Utah State University
}

Follow this and additional works at: https://digitalcommons.usu.edu/lib_pubs

Part of the Library and Information Science Commons

\section{Recommended Citation}

Betty Rozum, Lori J. Brassaw (2013), Merging Two Academic Libraries: Finding Unity from Diversity while Maintaining Institutional Identities, in Anne Woodsworth, W. David Penniman (ed.) Mergers and Alliances: The Operational View and Cases (Advances in Librarianship, Volume 37), Emerald Group Publishing Limited, pp.201-221

This Contribution to Book is brought to you for free and open access by the Libraries at DigitalCommons@USU. It has been accepted for inclusion in Library Faculty \& Staff Publications by an authorized administrator of DigitalCommons@USU. For more information, please contact digitalcommons@usu.edu.

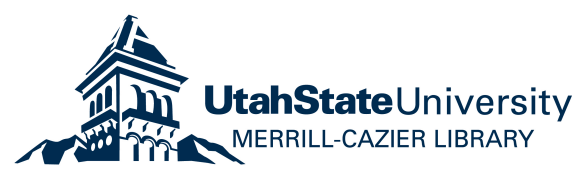


Merging Two Academic Libraries: Finding Unity from Diversity while Maintaining Institutional Identities

Betty Rozuma and Lori J. Brassaw

${ }^{a}$ Utah State University, Logan, UT, USA

${ }^{\mathrm{b}}$ Utah State University College of Eastern Utah, Price, UT, USA 


\begin{abstract}
Merging two distinct academic libraries into one presents unique problems and challenges. In 2010 the Utah System of Higher Education officially mandated that the College of Eastern Utah merge with Utah State University in order to reduce costs and promote efficiencies within the College of Eastern Utah, an institution hit particularly hard during the recent economic decline. Although the College of Eastern Utah was clearly becoming part of Utah State University, one of the charges was to maintain its core mission and unique identity. It was important that the College of Eastern Utah Library be seen as a separate entity, yet have full access to the resources of the Utah State University Library. Librarians at the respective institutions were charged with extending access to as many library resources as possible, streamlining workflow, eliminating redundancies, and uniting collaboratively as one working library. This chapter describes how they proceeded to fulfill this charge. Described are the practical aspects, such as migrating the College of Eastern Utah Library catalog to the same integrated library system and server as Utah State University's, as well as the steps taken to negotiate with vendors to provide access to electronic resources to all patrons. Changing technical services processes, organizing reference services and collection development, working with information technology staff at the different campuses, and budget management are also discussed. Two years later the two successfully moved forward as one academic library with separate institutional identities. Experience indicates that success was accomplished through collaboration, planning and effective communication.
\end{abstract}

Keywords: Academic libraries, mergers, collaboration, institutional identities

Classification: Case study 


\section{Introduction}

Until 2010, the Utah System of Higher Education in the U.S. was comprised of nine public institutions, which ranged from large, research-intensive schools with medical and law programs, to small community colleges. As in many states, the economic decline impacted different areas of Utah variously. The College of Eastern Utah, a community college, was hit particularly hard. In 2009 discussions were underway regarding the prospect of merging the College of Eastern Utah (CEU) with Utah State University (USU), a significantly larger research institution. A Memorandum of Understanding was drafted in July 2009 outlining the proposed merger. Since the merger was motivated in large part by the need to reduce costs, no additional ongoing funds were provided to facilitate merging these diverse academic institutions. The hope was that economy of scale would allow the two to operate efficiently as one, while retaining their core missions and unique identities. The merger was approved in the state legislature via Bill 69 in March 2010, and the College of Eastern Utah (CEU) was renamed Utah State University College of Eastern Utah, or USU Eastern (College of Eastern Utah Affiliation with Utah State University, 2010).

\section{Institutional Backgrounds}

Utah State University's main campus is in Logan, Utah at the northern end of the state, with three regional campuses and many smaller centers located throughout the state. USU is a landgrant university, founded in 1888 which offers 168 undergraduate degrees and 143 graduate degrees, including 40 doctoral and 94 master's level degrees. At the time of the merger USU's student headcount at the Logan campus was over 16,000. As of the 2010 census, the city of Logan had a population of 48,174 and its 400 -acre USU campus attracts students from throughout the state, the nation, and around the world.

The main campus of CEU is in Price, Utah, in the central eastern area of the state. The college has a satellite campus, the Blanding Campus, in Blanding, Utah near the south east corner of the state. Founded in 1937, CEU was established as a two-year community college with strong vocational technology programs. Over the years, its programs broadened to prepare students for upper-division courses at universities and it currently draws students from throughout the state and country, as well as some international students. Price has a population of 8,715 as of 2010 , and the college resides on a 12-acre campus. Blanding's population was 3,394 as of the 2010 census and CEU's campus there covers ten acres. Table 1 summarizes some of the main demographics of the two academic institutions. Pre-merger data are not available for $\mathrm{CEU}$, so the information here reflects post-merger numbers, but this accurately reflects the characteristics of both institutions before they were combined.

\section{TAKE IN TABLE 1}

With such diverse institutions, it follows that the libraries would reflect that diversity, and they do, in terms of the size, scope of collections, budgets, staff, and so forth. Table 2 provides an overview of the libraries at the time of the merger.

\section{TAKE IN TABLE 2}


While the differences between the two libraries were obvious before the merger, no one was fully prepared for the impact these differences would have on the libraries as the merger progressed from conceptual discussion to actual implementation.

This chapter discusses the challenges and processes of merging two previously autonomous academic libraries (the Merrill-Cazier Library at USU, hereafter referred to as USU), and the libraries of the College of Eastern Utah, (hereafter referred to as CEU) with different missions, histories, student populations, and collections into the Utah State University Libraries. Not only are the context and backgrounds of the institutions and their libraries described, but so are the manner in which operations such as technical services, reference, and other front line operations were merged.

\section{Negotiating and Implementing the Merger}

In a perfect world, undertakings such as mergers, library catalog systems migrations, and staffing reorganizations would be carried out with great forethought, planning, and analysis. Consultants would be hired to help make plans, which would be revised, tweaked, argued over, abandoned, and revived. Perhaps in the end a smooth transition would come about, but it certainly would require hard work, patience, and creativity. In this situation, discussion of the merger began eleven months prior to the official joining of the institutions. Both parties were concerned about committing resources and effort until the state legislature finalized the agreement, realizing the uncertain financial situation in the state could change the outcome at any point. Tentative planning therefore proceeded with caution, but circumstances demanded that some situations be addressed sooner.

Coincident with merger discussions in 2009, plans were underway to migrate CEU Library's online catalog (hosted by another academic library in the state), to that institution's newer integrated library system (ILS). This would have resulted in CEU having an ILS different from the one used at USU. Knowing the likelihood was great that the merger would be finalized, USU was willing to host CEU's ILS system and extend its SirsiDynix Symphony® system support even if the merger did not materialize.

\section{Communication}

Thus, even before formal merger discussions were complete, staff at the two libraries had begun working together in Fall 2009. The Dean of USU's Libraries visited staff at both the CEU Price and Blanding libraries to introduce himself and discuss prospects of the merger. By setting a collaborative and welcoming tone early, the Dean sent a clear message that everyone was in this situation together and that, while the libraries were clearly different, each had their own important mission to fulfill and that USU would be supportive of the CEU Libraries. Although the merger was not a "done deal," it seemed fairly clear that the State Legislature was strongly in favor of it and that it was in the libraries best interests to plan as if it were to take place.

In order to make the merger successful, personnel at both libraries had to learn to communicate comfortably with one another. Early in this process key USU staff members from the Logan campus made several trips to CEU's campuses. Additionally, the entire staff of the CEU Libraries visited USU's Logan campus. The distances from Logan to the USU's Eastern 
campuses are 200 miles to Price, and 390 miles to Blanding. Thus significant investment in travel was a measure of joint commitment. Additional visits would have been beneficial, but with such high cost in both time and money, the number was limited to four visits per year during 2009 and 2010.

\section{Migrating the Catalog}

Since catalog migration began before the State Legislature had approved merger of the two institutions, a strategy had to be developed for keeping bibliographic records separate and enable streamlining of technical services processing in the future. Bibliographic records of CEU's two libraries were brought into separate "libraries" or locations in USU's ILS so they could be searched independently at their respective locations. This was important on several levels. Should merger legislation not pass, records were separate and could be maintained independently by CEU staff. If the legislation did pass, USU could manage the records for CEU's libraries, enabling the students and faculty at each campus to see items from their local collection of about 91,000 records easily, without being overwhelmed by the $1.5 \mathrm{M}$ records from the USU collection. Tackling this step early provided the opportunity to get to know colleagues better and to begin discussing priorities for work, should the merger become official. Areas were identified that required immediate work such as aligning administrative library policies, providing access for the Price and Blanding campuses to the electronic resource that USU enjoyed, and consolidating technical services functions. USU staff gained additional benefits as a result of the systems migration such as familiarity with the holdings, cataloging practices, and general workflows of the CEU Libraries and insight into how best to centralize these functions in the future.

\section{Administration, Staff and Policies}

The library director at CEU had retired June 30, 2009, before the libraries began merger discussions, and an internal interim director had been appointed. With the merger officially approved, it was an opportune time to appoint the interim director to the position permanently and to restructure the reporting lines of the library. Prior to the merger CEU's libraries were administered jointly, with one director overseeing both sites (see Figure 1). Post merger the libraries were administratively separated with each reporting dually to its campus vice-chancellor and an associate dean at USU's library. Figure 2 illustrates the organization at the CEU Price Library. At the time this chapter was written, the library at Blanding had a parallel structure, with a vacancy for the director's position.

\section{TAKE IN FIGURE 1}

TAKE IN FIGURE 2

Before joining USU, librarians at CEU did not have faculty status; now they do. The new Director at Price entered the tenure track at USU in July 2011 as part of the library faculty. The Blanding Campus Library had a vacancy for a faculty librarian as of late 2012, and was staffed by two part time paraprofessionals. 
As soon as the merger became official in 2010, staff at both libraries thought it was important to align the policies and procedures quickly to match those of USU. This meant that all of CEU's policies, procedures and guidelines had to be reviewed and adjusted as necessary. For example, loan periods, fees and fines were changed to conform to those at USU.

While some changes were not well received, they were nevertheless necessary. Both of CEU's libraries had amassed large collections of popular reading materials, circulating music, and film on tape, DVD, and CD, which were available to the general public at no charge. While very popular with community members, the merger required that the libraries adopt a mission that focused on serving academic needs and the mission of the university rather than their communities, each of which had their own public libraries. CEU adopted the same borrowing and collecting policies as USU immediately, including charging the general public a fee to obtain borrowing cards.

This was a challenging adjustment for the staff and public patrons at CEU. Some patrons were frustrated by the fact that they no longer had easy access to popular materials and did not understand why the CEU library would no longer support their requests. CEU Library personnel feared they would be seen as a failure in the eyes of the public and by their campus administration when circulation statistics declined, as they naturally would when the library stopped functioning as a public library. Unpopular decisions had to be enforced in order to allow the CEU Library the opportunity to meet the needs of the new mission of the merged university.

The redirection of duties to library staff at USU resulted in nearly 30 hours per week of savings for the CEU Price staff. This, coupled with the resignation of a part time employee, created the perfect opportunity for the Director to assess staffing priorities and realign duties accordingly. One result was that a previous full-time paraprofessional cataloger at Price was refocused on library-related IT duties, overseeing Special Collections, and serving as the assistant to the Director. The Public Services Manager, thanks to streamlined procedures, had time to assist with general reference and instruction in the library, lead group tours, and offer library instruction lectures for "concurrent enrollment" students (i.e. students in high school taking college courses. The Technical Services Assistant, who until recently had ordered and processed all new book purchases, shifted to working closely with personnel at the USU Library to monitor purchases for CEU and participating in budgeting projects and reference duties.

Staff members at CEU, Price are currently tracking and evaluating their duties and responsibilities in anticipation of revised job descriptions, which will also help to identify the best use of one vacant position. Until new job descriptions are defined, it is essential that all staff remain flexible and willing to "go with the flow." Since there are only two part time paraprofessional staff members at the Blanding library, their job realignment has been minimal.

\section{Technical Services}

\section{Merging Operations}

Between 2008 and 2010 budget cuts at the USU Library resulted in the loss of $t$ ten positions and at CEU the Library lost one librarian position. Everyone was expected to do more with less: less

time; less staff. USU had streamlined technical services operations in response to budget cuts, so staff was primed to think creatively about how to take on additional work for CEU. Their 
solution was to move as much technical services processing and work as possible from CEU to USU.

The amount of materials ordered, received, and cataloged at CEU was minimal compared to the volume handled at USU. Other benefits for CEU included discounts from vendors for bulk purchasing and favorable service charge pricing from subscription agents. Responsibility for selection of material remained initially with staff at CEU libraries and would eventually be shared with subject librarians at USU. The goal was to integrate USU subject librarians fully into the selection processes at CEU by the end of 2012, similar to the way that CEU academic faculty members had been integrated into USU academic departments. For USU librarians this meant, in some instances, learning about new programs and curricula. For example, CEU has strong vocational education programs, most of which did not fall within the traditional fields of study that were familiar to librarians at USU. In other instances, students and faculty at CEU would benefit from the expertise that subject librarians at USU have developed through their ability to focus on one or two areas of study rather than the entire offerings of the college, as had been expected of the CEU Library Director. This collaboration between the libraries resulted in a stronger collection that reflects and supports the curriculum taught at CEU.

A trickier issue was how to bolster the collection at CEU with the limited budgets at the Price and Blanding libraries. Years of inadequate funding and inappropriate collection choices had left gaps in the collections. With the huge infusion of resources from USU, it was the perfect time to assess these collections to determine if they met newly revised curricular needs. Such evaluation would provide an opportunity to introduce faculty to the new resources and services available to them. Unfortunately, as with so many aspects of the merger, this would be an additional challenge for the staff who were still, as of the writing of this chapter, adapting to new roles or had already absorbed additional duties.

It was important for the librarians at each institution to maintain open communication to ensure that library collections supported learning in all fields offering USU degrees. This effort especially benefits CEU, since currently only one professional librarian serves the subject needs of all academic areas. Now there are numerous librarians who can share subject expertise in many disciplines, providing better service to the faculty and students.

\section{Materials purchasing.}

Identifying which items to purchase for CEU was the easy part. The more challenging problem was how to handle ordering, invoice payments and reconciliation, and general accounting and fund management. No new funding was provided, and existing funding remained at CEU, while the ordering, receiving, and acquisitions fund accounting functions were moved to USU as of July, 2010.

Managing purchases at USU allowed the libraries to take advantage of bulk discounts, and the relatively few orders placed were easy to fold into the workflow of USU's staff. Centralizing this work to USU freed CEU staff for other duties and spared them from learning the acquisitions module of a new ILS. Additionally, once orders were received, they were cataloged and processed, and then shipped to CEU, ready to be shelved.

On the downside of this process was the frustration it caused to CEU staff. While reports were provided monthly and on demand, it was confusing and unfamiliar to staff to not know instantly the status of the materials budget. Adding further frustration was the continual change experienced while the parent institutions worked out details of their financial systems. This 
required the libraries to annually develop new methods for handling the financial transactions between the sites.

\section{Interlibrary loan.}

Another area that seemed logical to streamline was interlibrary loan (ILL). CEU had tried to participate in interlibrary loan but had not been successful due to lack of staffing, training, and equipment. The service was not utilized well by faculty and students because of poor perceptions (e.g., materials took too long to arrive), and the number of requests received by the libraries was very low. These factors led to a joint decision to discontinue CEU's participation in interlibrary loan. Instead, the USU interlibrary loan staff handles the CEU requests, and items are either delivered electronically to a user account, or, if a physical item is requested, USU staff mail items directly to users with a stamped return envelope addressed to USU's ILL office.

In summary, centralizing technical services functions posed some challenges and required careful communication. Practices at USU that were considered standard did not necessarily work well for CEU. For example, the USU practice of removing and discarding book jackets when cataloging was not desirable at CEU. There, the library staff preferred to keep jackets for display purposes. Once USU staff were notified, it was easy to change the workflow pattern to retain book jackets and ship them along with the book to the CEU libraries. After staff at both libraries became comfortable with communicating openly with each other, any issues that did arise were quickly resolved.

\section{Electronic resources,}

Once the major aspects of the centralization of technical services were well underway, librarians began to examine how best to provide access to electronic resources. With an extensive distance education program, USU had aggressively purchased or leased access to numerous electronic resources and by July 2010 had access to over 250 databases, over 40,000 electronic journals, and nearly 400,000 electronic books. In contrast, CEU had access to relatively few electronic resources, and only three databases which were unique to CEU as a whole.

The first task to address was how to provide access to e-books in the catalog. License agreements varied, making some e-books accessible only to CEU, while others were limited to USU, and a third group was licensed for use by both institutions. A working group of librarians came up with an elegant solution. Catalogers created a separate "library," as it was called in the Symphony ${ }^{\circledR}$ system, to house records for electronic resources which could be accessed by members of both campuses. These resources were known as "shared" resources. Resources restricted to patrons of one campus or the other were then left in the "library" that corresponded to that campus. Default OPAC searches were set to query the home campus plus the "shared" electronic resources to CEU. In other words, the online catalog at CEU was set to search its own catalog of 91,000 records plus the library of shared electronic resources. The online catalog at the Logan campus was set to search its own collection of about 1.5 million records plus the shared electronic resources. This allowed movement of resources in and out of the shared library and local libraries as access to electronic resources for CEU was negotiated.

Providing a portal via the catalog was perhaps the easiest step in expanding access to electronic resources to CEU. Under the best circumstances, the staff at CEU would have been trained and fully involved in the processes. Geographic and temporal barriers made this 
infeasible. Therefore staff at USU faced the laborious tasks of reviewing all licenses for the resources they owned and negotiating access to them for CEU.

Librarians at USU developed a plan to address the process systematically and streamlined it as much as possible. First, a prioritized list of resources that should be made available to CEU was created. The steps of the plan were to:

- Ask permission to add CEU to the existing USU licenses;

- Send the vendor/publisher the Internet Protocol (IP) ranges to add;

- Verify access at CEU's Price and Blanding locations; and

- Provide access to the resources through some sort of website portal

USU's ultimate goal was to provide access to all electronic resources, but this would have been financially unrealistic without an infusion of ongoing funding. Vendors would be reluctant to give content to a site for free, when that organization could purchase it. When deciding how to extend the existing access of USU's licenses as far as legally possible, or transferring management of CEU's access to personnel at USU, a number of factors were considered.

A multipronged approach was taken that involved first negotiating with vendors familiar with CEU. Then, for resources which had prices based on the number of full time equivalent (FTE) students and for which the combined FTE of the two campuses would not bump costs into a higher price range, the companies were contacted next. For example, if CEU's FTE count could be added to the USU FTE without pushing prices into the next tier, the product licensed to include CEU. Finally USU librarians called vendors who were not likely to view CEU as a lost sale, such as producers of some of the larger electronic journal packages that are geared to advanced study. This allowed USU to extend access to a vast number of electronic resources to CEU in a relatively short amount of time.

Next the providers of the remaining journal packages and individual databases were contacted. Librarians developed a script, and the work was divided among a handful of staff with experience in negotiating licenses at USU. When not successful in obtaining permission to extend access to CEU, quotes for pricing were obtained. In some instances access was purchased when it was determined that the product was essential for the mission of CEU.

The final process was to determine which of the non-bundled electronic journals would be made accessible to CEU. When processing renewals, USU's subscription agent asked vendors to include the IP range for both USU and CEU and USU is currently verifying access and manually adding the IP ranges to publishers' records when needed.

This provides an overview of the process, but details are what make or break a project of this magnitude. It was critical to have a method to track the progress of which electronic journals were negotiated. Perhaps more importantly, from a public relations point of view, was to have a way to let users know which resources they could access. To do this, USU duplicated and modified a homegrown database developed to serve up the USU databases and mounted this on the CEU library website. This provided a means to activate resources and provide accurate links for online access.

Indicating rights to electronic journals was more complex. USU uses SerialsSolution ${ }^{\circledR}$ as its link resolver and to present an A-Z listing of electronic journals available to patrons. USU needed a creative solution to presenting different access rights for CEU, while using a single installation of SerialsSolutions ${ }^{\circledR}$. Librarians developed the idea of placing a note in the record for those electronic journals not accessible to students at CEU. When USU students used the link resolver, they were directed to search the library's online catalog if an article were not available 
online, whereas a note instructed CEU users to proceed directly to interlibrary loan to request the article. This arrangement was appropriate because the serial holdings of CEU are so limited that it is more efficient for users to bypass the step of searching their local catalog.

A major challenge to the implementation of additional online resources was trouble shooting. Staff at both CEU sites lacked the technical expertise to trouble shoot to any depth. USU librarians had difficulty determining whether a new resource really was working at both the Price and Blanding campuses, which had different firewall issues. The solution was for USU personnel to install a computer at CEU, Price which allowed them to log in remotely and test the access to the electronic resources there and to do the same at CEU, Blanding later in 2012.

\section{Library websites.}

At USU, the Library has complete control over its own website, purchasing and maintaining the server, and programming the site. This allows USU to be highly responsive to changes that need to be made. In contrast, the CEU libraries' websites had been managed by each campus' Information Technology (IT) staff. Library staff at CEU worked with IT personnel to plan the content, but IT employees, as their schedule and workload permitted, implemented these changes. With USU providing access to a wide variety of resources via different interfaces for CEU, a new library IT operating model had to be identified and implemented to support these new resources and services.

USU library staff worked with the IT staff at both CEU libraries to develop a new model to maintain and update the website efficiently and effectively. While the approach was the same for each campus, the reaction and reception to the proposed change differed in the two communities. The CEU Blanding IT staff were willing to provide the information necessary to transfer their library website to the USU's server, whereas the CEU Price IT staff were reluctant to support such a change. Additional negotiations were required to gain support and acceptance. It took much longer to work out IT related issues at the Price campus, because of political, rather than technical, issues.

With USU managing both CEU Library websites, it became easy to update and make changes to design and content. The USU Digital Services Librarian met with library staff from both CEU campuses to obtain their perspectives on the needs of their users and then conducted web usability studies with students to make sure the websites accommodated local populations well. The resulting websites for CEU libraries reflect their identities and local resources, and streamlined management under one web team provides stability and facilitates communication.

In hindsight the time -- nearly 18 months -- and effort required to centralize the bulk of the technical services functions was more than anyone anticipated. As Locke (2007) stated "There is also agreement in the literature that mergers are very time consuming and resource intensive processes - before, during and after the actual event - and that this is underestimated more often than not"'(p.89).

\section{Public Services}

After the technical services functions had been solidly centralized, the electronic resources launched, and website management transferred, it was time to turn to public services offerings at the CEU libraries. One of the first considerations was the course reserves system. USU uses Docutek ERes to provide electronic access to scanned versions of faculty syllabi, articles not 
available full text through paid subscriptions, and other resources allowed within the limits of copyright. Both CEU libraries lacked the software and expertise to offer this service to their users. CEU Price moved to this system first, and CEU Blanding will follow in 2013. Books and materials that cannot be digitized due to copyright considerations would remain in physical collections under the traditional print reserves model. All other materials would be scanned at CEU and sent to staff at USU who would process and add them to the CEU e-Reserves collection. As with the technical services processing, the volume of electronic reserves processing that USU library staff handled enabled them to develop expertise in Docutek ERes and familiarity with copyright rules. In addition, the materials could be housed on the server at USU, preventing the need for CEU to purchase new equipment.

CEU had never used the Docutek ERes system, so having USU staff take care of the bulk of the work also freed CEU staff from having to learn a new system. An added benefit was that students, who are groomed to transfer to USU to complete a four-year degree, are becoming familiar with a system that they will likely use in the latter phase of their college education.

At the time of the merger in 2010 all patron and staff computers at both CEU Price and Blanding were very old. The Dean of the USU Library determined that it was critical for both libraries to upgrade to new computers. As this was an expensive outlay of funds, the Dean worked with the respective vice-chancellors of each CEU campus to reach an agreement whereby USU would split the cost of new computers with the CEU campus administrations.

Purchasing new computers was easy compared to campus political issues surrounding loading, delivering and maintaining the newly purchased library workstations at CEU Price. Traditionally, the CEU libraries selected, ordered, and paid for all library computers from the library budget. The campus IT Departments at CEU would then prepare the computers for usage. However, at USU, all library computers and software are installed and maintained by the Library Information Systems (IS) staff. USU Library IS staff purchased the new computers for the CEU Libraries and prepared them for installation, but it was necessary to reach an agreement with their IT units for maintaining the machines prior to delivery.

It was essential to outline expectations and responsibilities carefully and completely for the IS and IT staff at both USU and CEU libraries regarding maintenance and updating of the computers. This took more time and effort than initially anticipated because of political issues, not technical hurdles, that had to be addressed and resolved in order to move forward at CEU Price. Fortunately, the IT staff members at CEU Blanding were amenable to working cooperatively with USU Library IS personnel, so installation went much more smoothly.

\section{Reference and Instruction}

Providing access to additional resources to users at CEU was only the first step. They needed help with how to find and use these products. As internal web usability studies revealed, students at CEU had markedly different skill levels for navigating library resources than did the students at USU. This highlighted the need to increase all librarians' awareness of the discrepancy between the campuses with respect to information literacy.

Subject librarians at USU serve as liaisons to academic departments, select materials for their subject areas, and provide reference and instruction. Since they provided these services to CEU Libraries as well, with the exception of collecting materials (which they began to do at the end of 2012), they needed to gain greater awareness of the typical CEU student's research aptitude and curricula specific to the campuses. CEU's faculty members were incorporated into 
the infrastructure of academic departments on the USU campus. They attend yearly departmental retreats at the USU campus, which the USU subject librarians attend. The USU librarians were able to meet the faculty from CEU, and explain the services they could provide for both classroom instruction and the faculty member's own research needs. As USU librarians had to learn about a new population, library employees at CEU's Price and Blanding campuses had to become proficient in searching both the handful of new, core databases they had and the abundance of specialized subject databases recently made available to them.

Recognizing the geographic distance between the campuses, the library employs resources such as LibGuides (on-line subject and course-specific web pages that can include tutorials and videos), interactive broadcast, and electronic chat reference to connect faculty, students, and librarians across the state. As of the writing of this chapter, chat reference service is provided to users at CEU, but unknown to them, they are being served by librarians at USUanother example of streamlining of services. Similarly, librarians at USU created LibGuides for specific subjects for CEU Library as a means to help promote resources and raise awareness about access to library resources.

\section{Cost of the Merger}

What did the merger end up costing the libraries? Operating as one organization resulted in shifting of librarian and staff duties. While savings from reduced staff were realized at the CEU campuses, there were real costs passed on to USU. The first two years after the merger (July 2009 to June 2011) required a significant investment of staff time at USU. In addition, USU bore concrete costs for items such as computers, hardware, shipping fees, etc. Table 3 summarizes the expenses borne by USU for these tangible items. Some were one time purchases, but as mentioned earlier, USU has committed ongoing funds to electronic resources, shipping materials to CEU, paying for interlibrary loan, and also supporting travel for USU and CEU personnel. The USU Campus Administration did supply $\$ 100,000$ to offset the costs of the merger, but that amount was expended within the first year. The USU Library plans to continue to support these additional costs in the future since it is likely that the demand for electronic resources y will increase and the remaining "USU only" products will be licensed, for an additional fee of course, to include CEU's campuses. CEU did see an increase in travel costs associated with trips to USU, and these costs are also anticipated to continue (Table 4).

\section{TAKE IN TABLE 3}

\section{TAKE IN TABLE 4}

The most significant cost, from the perspective of USU, was the cost of staff. While CEU realized a savings of about 30 staff hours per week through the merger, USU gained just over 30 hours of additional work per week. Table 5 summarizes the division of the duties among the various units at USU. While an hour here and there is not that much more for a relatively large library to manage, the overall effect was indeed felt, especially in light of a $10 \%$ decrease in staff at USU due to budget cuts. The first two years of the merger were especially intense, requiring an even greater investment of USU staff time. Table 6 summarizes the time that was devoted to the project during the first two years, and Table 7 provides the costs, based on actual salaries at USU, for the one time and ongoing work provided to the CEU campuses. 
TAKE IN TABLE 6

TAKE IN TABLE 7

The time required from USU Library IS department was the most significant. This unit continues to be taxed heavily post-merger. The cataloging department at USU, which was especially hard hit by staffing cuts, also carried a heavier load than most other departments postmerger. This was anticipated however, since the plan had always been to move all technical services to USU.

While the staff has not increased, nor were there library budget cuts, the library staff at USU and CEU have managed to accomplish quite a bit in the short time during which they became united as one staff. The Table 8 below provides comparative data for the first year of post-merger operation s. The reduction in volumes held at CEU was due to removal of the popular reading and media materials.

\section{TAKE IN TABLE 8}

\section{Discussion}

In the end, the merger was successful in many ways. Beyond accomplishing the directive of providing access to resources to the patrons of CEU, the experience allowed two very different libraries to learn to work together as one. Staff at both libraries learned from one another. While the merger came with expenses, the CEU Libraries certainly realized savings from changes in staffing and streamlined operations. Students and faculty at CEU benefited from access to a wealth of resources previously not accessible to them. From the perspective of the staff at the USU Library, in addition to the opportunity to face new challenges successfully, much was learned about students and faculty at the new sister campuses and the programs offered there. This helped to strengthen the library's web presence and made subject librarians more aware of the importance of electronic resources for distance students and for students and faculty at CEU.

Although the directive was to merge libraries while maintaining distinct institutional identities and to keep the budgets separate to the degree possible, it is evident that these will quickly blur as academic programs and services at the institutions become more blended. CEU is adding more programs and classes, with the result that it becomes increasingly difficult to determine the budgets from which expenses should be paid. It is easy to keep a "public" face of serving up resources through a different website, but the background work of selecting, purchasing, and processing these resources will become increasingly mixed. Likewise, it is anticipated that USU based librarians will be the primary providers of reference and instructional services to library users at the two CEU campuses. As the libraries move forward, keeping the identities distinct will become more challenging, perhaps less important, and likely in the end, barely discernable.

\section{Key Lessons}


There were lessons learned, although none were too surprising, which could be useful to other libraries in, or anticipating, similar situations.

\section{Communication.}

This should be a top priority. In spite of attempts to communicate frequently, distance was a barrier. Virtual meeting technology should have been utilized more effectively. Librarians did keep and share notes of meetings when they remembered, but this should have been made a requirement for all trips and projects, with a set schedule for dissemination to people at all campuses. This would have ensured better communication all around.

\section{Staff concerns and stress.}

Questions voiced by staff should be should be encouraged and addressed to ensure that they understand that difficult choices and decisions must be made. Staff at CEU had to adapt to changing policies, collections and duties. Staff at USU had to take on additional duties. Compromise was required and it was important for library management to provide clear expectations and encouragement during difficult transition periods (see Communication).

\section{Time management.}

Time should be managed as carefully as finances. This is one area in which USU could have done better. The amount of time it took to plan and implement the merger as it was underway was enormous. The USU staff who participated in the work were not relieved of any other previous duties and the stress on staff due to managing the time required for the merger, plus their day-to-day tasks, took a toll. In some instances people fell behind in their jobs. In other cases, morale suffered. USU routinely underestimated the amount of staff time it would take to complete merger related work. With hindsight, it would have been better to reassign duties of key personnel working on the merger, and to identify projects or tasks in various departments that could be ignored for the duration of the merger. This would have relieved a considerable amount of stress on the part of USU staff.

\section{Mistakes and learning processes.}

Accept that mistakes will be made and workflows will need to be changed. It took several attempts to find a workable solution to processing payments for CEU's books and journals before finding a solution that worked. As staff learned new duties at CEU, it was important that they understand that mistakes were expected and part of the learning process. The merger is an evolving process and it is expected that duties and workloads will continue to change.

The framework for the merger of the USU and CEU Libraries has been put into place, yet much work remains to be done. In the years ahead the libraries will continue to strengthen their ties and improve upon the processes developed so far. As learned through the merger in Utah, and as numerous others have stated (Muhonen, Nygrén \& Saarti; Swanepoel, 2004; Weaver, 2008), communication is the single most important tool in a kit for successful mergers to result. 
The USU and CEU Library staff have learned much from this experience, and the future is certain to provide more opportunities to apply the lessons learned thus far. 


\section{References}

College of Eastern Utah Affiliation with Utah State University, S.B. 69 Utah Gen. Sess. § 211973 (2010). Retrieved from http://le.utah.gov/ 2010/htmdoc/sbillhtm/sb0069s01.htm

Locke, W. (2007). Higher education mergers: Integrating organizational cultures and developing appropriate management styles. Higher Education Quarterly, 61(1), 83-102. doi:10.1111/j.1468-2273.2007.00339.x

Muhonen, A., Nygrén, U., \& Saarti, J. (2011). Bringing order out of chaos: Benchmarking tools used in merging university libraries in Finland. In A. Woodsworth (Ed.), Advances in Librarianship: Librarianship in times of crisis (pp. 183-205). Bingley, UK: Emerald Group. doi.org/10.1108/S0065-2830(2011)0000034012

Swanepoel, A. (2004). Concerns and expectations of library staff before and after a merger. Iatul Proceedings (pp.1-10). Retrieved from http://www.iatul.org/doclibrary/public/Conf_Proceedings/2004/Adriaan20Swanepoel.pd $\mathrm{f}$

Weaver, M. (2008). More than the sum of its parts: A university for Cumbria. New Review of Academic Librarianship, 14(1-2), 79-98. doi:10.1080/13614530802519279 


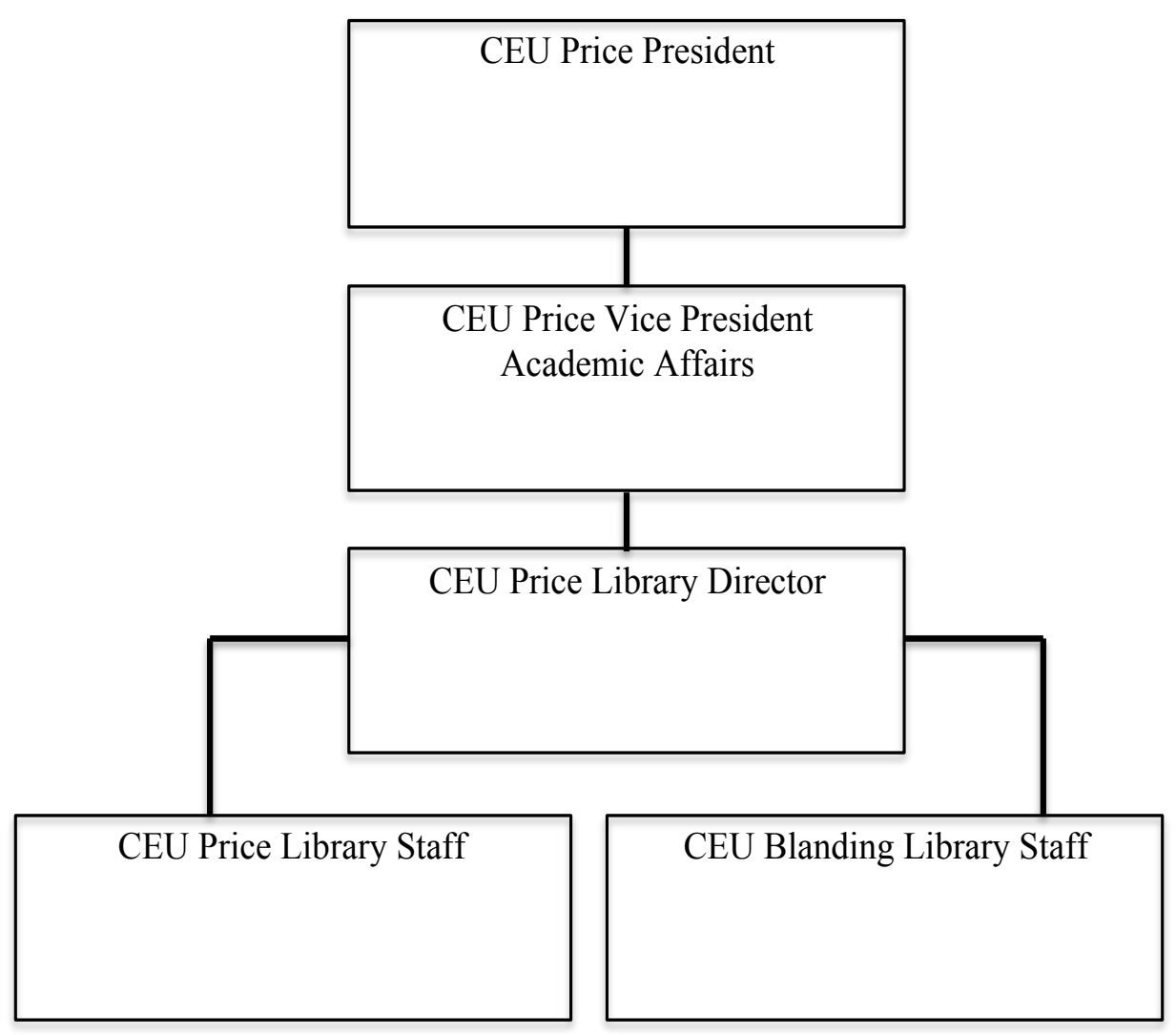

Fig. 1 Organization chart for CEU (pre-merger). 


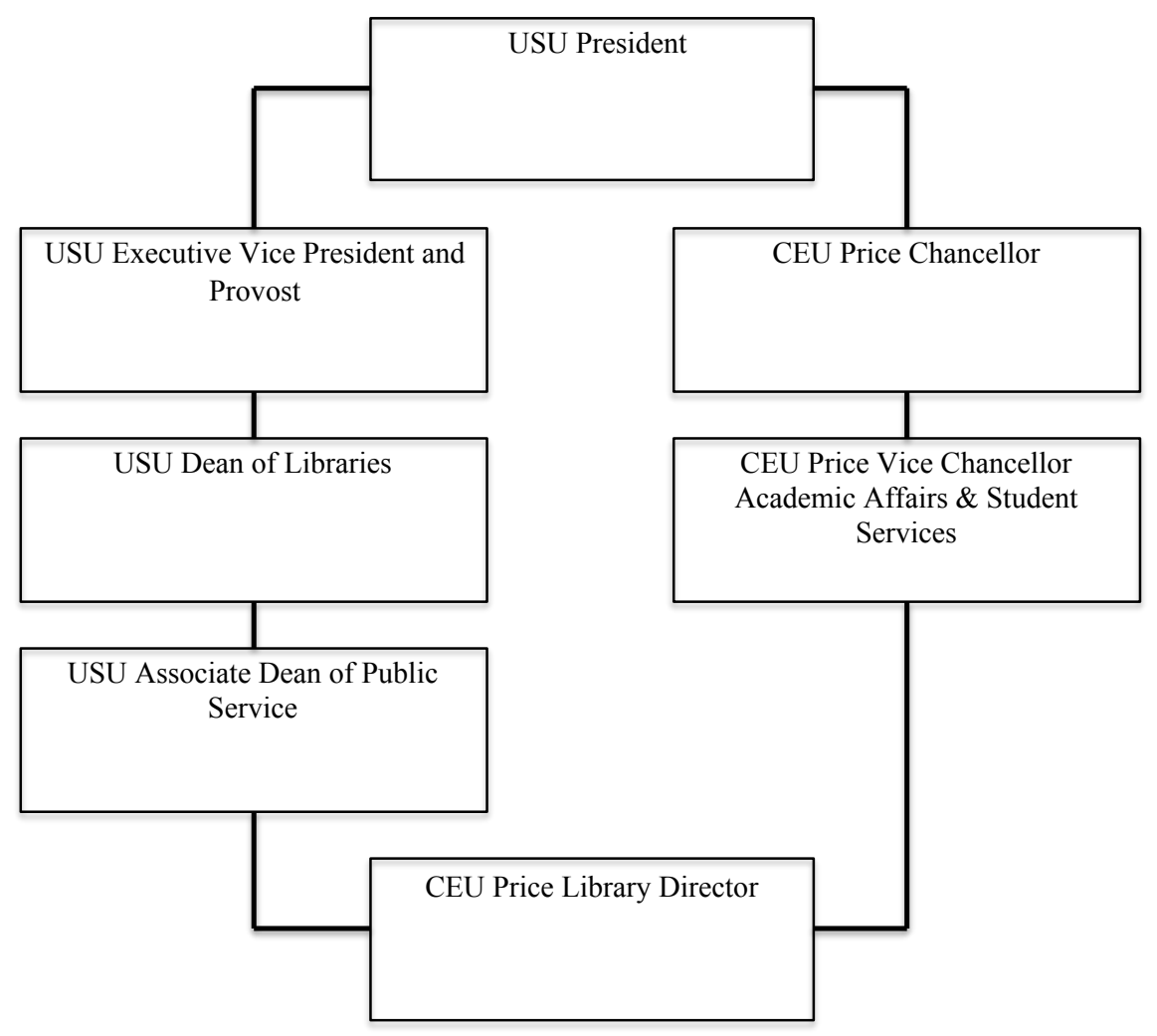

Fig. 2 Organization chart for CEU Price (post-merger). 


\section{Table 1}

Institutional Overview (Fall 2011)

\begin{tabular}{lccccc}
\hline \multicolumn{1}{c}{ Institution } & Head Count & FTE & $\begin{array}{c}\text { Undergraduate } \\
\text { Degrees }\end{array}$ & $\begin{array}{c}\text { Graduate } \\
\text { Degrees }\end{array}$ & Faculty \\
\hline $\begin{array}{l}\text { CEU (Price } \\
\text { \& Blanding }\end{array}$ & 2,323 & $1,522.9$ & 2 & 0 & 64 \\
USU & 29,507 & 13,833 & 168 & 143 & 972 \\
\hline
\end{tabular}

Table 2

Comparative Library Data, June 2010 (Pre-Merger)

\begin{tabular}{lccccc}
\hline & $\begin{array}{c}\text { Library } \\
\text { Fulltime } \\
\text { Staff (non- } \\
\text { professional) }\end{array}$ & $\begin{array}{c}\text { Professional } \\
\text { Librarians }\end{array}$ & $\begin{array}{c}\text { Library } \\
\text { Visitors }\end{array}$ & $\begin{array}{c}\text { Volumes } \\
\text { held }\end{array}$ & $\begin{array}{c}\text { Total } \\
\text { Library } \\
\text { Budget }\end{array}$ \\
\hline $\begin{array}{l}\text { CEU } \\
\text { Libraries }\end{array}$ & 6 & 1 & 70,176 & 87,279 & $\$ 413,800$ \\
USU Library & 25 & 38 & 977,833 & $1,595,163$ & $\$ 8,222,648$ \\
\hline
\end{tabular}

Table 3

Costs Borne by USU Library

\begin{tabular}{lcc}
\hline & One-Time & Ongoing \\
\hline Collection Supplies \& & $\$ 4,226$ & $\$ 245$ \\
Services & & \\
Collections & $\$ 18,027$ & $\$ 26,182$ \\
Computers & $\$ 56,082$ & \\
Travel and Training & $\$ 6,644$ & $\$ 4,659$ \\
Total & $\$ 84,979$ & $\$ 31,086$ \\
\hline
\end{tabular}

Table 4

Costs Borne by CEU 
Library

\begin{tabular}{lcc}
\hline & One-Time & Ongoing \\
\hline Travel and Training & $\$ 5,052$ & $\$ 1,947$ \\
\hline
\end{tabular}

Table 5

Division of Duties Among Units at USU

\begin{tabular}{|c|c|}
\hline Staff Area & Hours per week \\
\hline Cataloging & 6.5 \\
\hline Acquisitions & 1 \\
\hline Systems & 10 \\
\hline Digital Librarian & 1 \\
\hline Administration & 7 \\
\hline Circulation & 4 \\
\hline Collections & 1 \\
\hline Course Reserves & 1 \\
\hline Total & 31.5 \\
\hline
\end{tabular}

\section{Table 6}

Staff Time Spent by Area at USU During First Two Years of Merger

\begin{tabular}{lc}
\multicolumn{1}{c}{ Staff Area } & Time \\
& (Hours) \\
\hline Negotiating licenses (various staff) & 40 \\
Systems & 5,000 \\
Digital Librarian & 170 \\
Administration & 1,100 \\
Circulation & 26 \\
Collections & 770 \\
Course Reserves & 16 \\
Special Collections & 58 \\
Total & 7,180 \\
\hline
\end{tabular}

\section{Table 7}


USU Costs in Staff Time Planning and Implementation

\begin{tabular}{lccc}
\hline & Hours per year & Cost & FTE \\
\hline Initial & 3,590 & $\$ 321,671$ & 1.7 \\
Ongoing & 1,643 & $\$ 62,816$ & 0.8 \\
\hline
\end{tabular}

Table 8

Comparative Library Data, June, 2012 (Post-Merger)

\begin{tabular}{lccccc}
\hline & $\begin{array}{l}\text { Library } \\
\text { Fulltime } \\
\text { Staff (non- } \\
\text { professional) }\end{array}$ & $\begin{array}{c}\text { Professional } \\
\text { Librarians }\end{array}$ & $\begin{array}{c}\text { Library } \\
\text { Visitors }\end{array}$ & $\begin{array}{c}\text { Volumes } \\
\text { held }\end{array}$ & $\begin{array}{c}\text { Total } \\
\text { Library } \\
\text { Budget }\end{array}$ \\
\hline $\begin{array}{l}\text { CEU } \\
\text { Libraries }\end{array}$ & 6 & 1 & 69,562 & 73,909 & $\$ 302,852$ \\
USU Library & 24 & 37 & $1,004,137$ & $1,670,395$ & $\$ 7,879,598$ \\
\hline
\end{tabular}

